\title{
HEALTH EXPENDITURE AND ECONOMIC GROWTH: IS THE HEALTH- LED GROWTH HYPOTHESIS SUPPORTED FOR SELECTED OECD COUNTRIES?
}

\author{
Ayşe Özge Artekin ${ }^{6}$ \& Sevilay Konya ${ }^{7}$
}

UDC / UDK: 614:657.471:338.1OECD

JEL classification / JEL klasifikacija: N3, O4

DOI: https://doi.org/10.22598/pi-be/2020.14.1.77

Preliminary communication / Prethodno prioćenje

Received / Primljeno: October 21, 2019 / 21. listopada 2019.

Accepted for publishing / Prihvaćeno za tisak: February 10, 2020 / 10. veljače 2020 .

\section{Summary}

The aim of this study was to investigate the health-led growth hypothesis in selected 19 OECD countries. Therefore, in this study, different cointegration tests were applied to investigate the relationship between health expenditures and economic growth for the period 1980-2017. The coefficients of the panel regression equation were estimated by the fixed effect method. According to the results, long-term relationship between health expenditures and economic growth was found. Health-led growth hypothesis for selected OECD countries (Australia, Austria, Belgium, Canada, Denmark, Finland, Iceland, Ireland, Japan, Korea, Netherlands, Norway, Portugal, Spain, Sweden, Switzerland, Turkey, United Kingdom, United States) are supported. That is, a long-term relationship between health expenditure and economic growth has been found.

Key words: Health-Led Growth, Cointegration Test, OECD Countries.

${ }^{6}$ Ayşe Özge Artekin, Ph.D. Candidate, Selçuk University, Department of Finance Banking and Insurance, Yunak Vocational School, Turkey, E-mail: aoartekin@selcuk.edu.tr

7 Sevilay Konya, Ph.D., Selçuk University, Department of Management and Organization, Taşkent Vocational School, Turkey, E-mail: sevilaykonya@selcuk.edu.tr 


\section{INTRODUCTION}

Economic growth, which is expressed as the continuous increase in production and per capita income compared to the previous year, is one of the subjects that all the developed and developing economies now focus on. In this case, health expenditures, which is one of the clear indicators of the health system and accelerates economic growth by increasing the human capital of countries, becomes more important for countries.

Health expenditures of countries around the world are increasing year by year. It is seen that the health resources and health expenditures of the countries in the OECD have increased significantly. The reason for the increase in health expenditures; factors such as increase in income level, labor-intensive health sector, increased life expectancy and cost of high technology used in health sector. The increase in health services increases both the productivity and quality of life and the social development of the society. The high number of healthy individuals in the society has a positive effect on economic productivity by preventing labor losses and increasing productivity. Therefore, increasing health expenditures play a significant role in the economic growth and development of countries by improving human capital from day to day.

The main purpose of the study is to investigate the impact of the health expenditures OECD group countries including Turkey on economic growth. Our study consists of four sections. Firstly, a literature review about the subject will be made. In the second part, the source of the data and descriptive statistics will be included. In the third chapter, the empirical results and the econometric methods used in the study will be discussed. In the final part of the study, brief summary, constraints and policy recommendations will be expressed.

\section{LITERATURE REVIEW}

There are many studies in the literature that examine the relationship between health expenditures and economic growth. However, because our study is based on 19 selected OECD countries (Australia, Austria, Belgium, Canada, Denmark, Finland, Iceland, Ireland, Japan, Korea, Netherlands, Norway, Portugal, Spain, Sweden, Switzerland, Turkey, United Kingdom, United States). Our literature review has been composed of publications which have worked on OECD countries.

Hansen and King (1996) tested the relationship between GDP and per capita health expenditures in 20 OECD countries with unit root analysis. In the results obtained from the study, it was found that the series were not stable and that the GDP was an assing factor in find out the level of total health expenditures.

Heshmati (2001) tested the causality relationship between GDP and per capita health expenditures in OECD countries in the period of 1970-1992. As a result of the research conducted within the scope of the extended Solow model, health expenditures per capita have a positive effect on economic growth and these expenditures affect the convergence velocity of countries. 
Gyimah-Brempong and Wilson (2004) analyzed the impact of life expectancy and total health expenditure on the per capita income growth for the Sub-Saharan African and 23 OECD countries in the 1961-1995 period by using the expanded Solow Model. In conclusion, it is reported that total health expenditures and life expectancy at birth have a positive and strong effect on per capita income growth.

Beraldo et al. (2009), for the period 1971-1998; examined the effects of public and private health and education expenditures on GDP for 19 OECD countries by using panel analysis method. In the analysis, there is a important positive relationship between health and education expenditures and GDP growth. Estimates shows that a 1\% increase in total health expenditure growth rate would increase the per-capita GDP growth rate by about $0.06-0.10 \%$.

Hartwig (2010) discussed the relationship between health expenditures, increase in human capital accumulation and life expectancy level at birth and economic growth in the context of the causality analysis. The results do not support the view that health capital formation promotes long-term economic growth in the OECD region.

Çetin and Ecevit (2010) tested the effects of health on economic growth in panel studies with 15 OECD countries between 1990 and 2006. In the analyzes, the authors found a weak positive relationship between health expenditures and economic growth and concluded that this relationship was not statistically significant.

Baltagi and Moscone (2010) examined the relationship between health expenditures and economic growth for the period of 1971-2004 in 20 OECD countries with panel data method. In the study, the authors concluded that in the long term health expenditures and economic growth are interrelated. This study shows that health expenditures are a necessity rather than a luxury.

Yerdelen (2011) conducted a study using health data and income per capita covering 20 OECD countries using data from 1975-2005 period. In this study, the stationarity of the GDP and health expenditures series were examined. In addition, the existence of a cointegrated relationship between the two series was analyzed. As a result of the study, in the short and long term; it has been shown that every additional investment in the field of health has an effect on growth.

Yardımcioglu (2012) in the period of 1975-2008, has investigated the relationship between economic growth and health for 25 OECD countries. In this study, Pedroni cointegration test, Pedroni FMOLS test and Canning; Pedroni panel causality analysis used. As a result of the analysis, it was found that there was a mutual and positive relationship between health and economic growth variables in the long term.

Wang (2015) aims to estimate optimal health expenditures in a growing economy. In this context, between 1990 and 2009, it analyzed the data of OECD countries by GMM method. Empirical evidence shows that when the ratio of health spending to gross domestic product (GDP) is less than the optimal level of $7.55 \%$, increases in health spending effectively lead to better economic effect.

Badri and Badri (2016) analyzed the relationship between total health expenditure and economic growth by using Generalized Method of Moments (GMM) data for 2006-2013 period for selected 24 OECD countries. According to the results obtained from the study, health expenditures in selected countries have a significant and 
positive effect on economic growth. In addition to, it was concluded that health expenditures increased by $1 \%$ and economic growth increased by $0.4 \%$.

Kamac1 and Yazic1 (2017) tested the relationship between the share of health expenditures in GDP and economic growth through panel data analysis. In the study, data for 2000-2014 years were used for 35 OECD countries. According to the results of the study, a two-way causal relationship was found between the two variables.

Tıraş and Ağır (2018) explained the relationship between types of income and health spending in the case of OECD countries by using panel causality test. As a result of the estimates, approximately $80 \%$ of OECD countries, have found a causal relationship between income and at least one of the types of health spending. However, the increase in income in these countries increases the maximum total health expenditures and the increase in public health expenditures leads to an increase in income.

Uslu (2018) examined the effects of health expenditures on economic growth in 36 OECD countries for the period 1995-2017 with dynamic panel data analysis. In the long-term analysis, $1 \%$ increase in per capita health expenditure increases per capita national income by $0.26 \%$. As a result of the analysis, it has been determined that there is a very strong and mutual causality relationship between health expenditures, economic growth and fixed capital stock in OECD countries.

K1lıç and Özbek (2018) the relationship between health expenditure, education spending and economic growth were tested by using panel data analysis for Turkey and 32 OECD countries between 1995-2013. According to the results of the causality test, bi-directional causality relationships were determined between health expenditures, education expenditures and economic growth variables at 5\% significance level. As a result of the study, it was found that health expenditures, education expenditures and economic growth positively affect each other.

Different analyzes and methods are used in the studies on health expenditures and economic growth. In addition, the diversity of the countries and the years covered are varied. In the studies, the relationship between health expenditures and economic growth was examined and according to the results of the study, Heshmati (2001), Gyimah-Brempong and Wilson (2004), Beraldo and di $\breve{g}$. (2009), Yerdelen (2011), Yardımcıoğlu (2012), Wang (2015), Badri and Badri (2016), Tıraş and Ağır (2018), Uslu (2018), Kamacı and Yazıcı (2017) and Kılıç and Özbek (2018), stated that the increase in health expenditures had a positive effect on economic growth. On the contrary, Hartwig (2010) rejects the view that health expenditures support long-term economic growth in the OECD region. Çetin and Ecevit (2010) found a weak positive relationship between health expenditures and economic growth. These studies constitute a source for our studies and our study supports some findings. 


\section{DATA AND DESCRIPTIVE STATISTICS}

In this study, 19 OECD countries were discussed. Based on the literature, dependent variable was taken as economic growth and explanatory variables were taken as health expenditure, life expectancy, infant mortality rate and population growth rate. The variables used in the study and their sources are summarized in the table below.

Table 1. Information About the Data

\begin{tabular}{|l|l|l|l|l|}
\hline Variables & Abbreviation & Period & Description & Source \\
\hline Economic Growth & $\operatorname{lnGDP}$ & $1980-2017$ & GDP Per Capita (\$) & OECD \\
\hline $\begin{array}{l}\text { Health } \\
\text { Expenditure }\end{array}$ & $\ln \mathrm{HE}$ & $1980-2017$ & $\begin{array}{l}\text { Health Expenditure } \\
\text { (US dollars/capita) }\end{array}$ & OECD \\
\hline Life Expentancy & $\operatorname{lnLE}$ & $1980-2017$ & $\begin{array}{l}\text { Life expentancy at } \\
\text { birth, total(years) }\end{array}$ & $\begin{array}{l}\text { World } \\
\text { Bank }\end{array}$ \\
\hline $\begin{array}{l}\text { Infant Mortality } \\
\text { Rate }\end{array}$ & $\operatorname{lnIMR}$ & $1980-2017$ & $\begin{array}{l}\text { Mortality rate, } \\
\text { infant (per 1,000 } \\
\text { live births) }\end{array}$ & $\begin{array}{l}\text { World } \\
\text { Bank }\end{array}$ \\
\hline $\begin{array}{l}\text { Population } \\
\text { Growth }\end{array}$ & POP & $1980-2017$ & $\begin{array}{l}\text { Population Growth } \\
\text { (annual, \%) }\end{array}$ & $\begin{array}{l}\text { World } \\
\text { Bank }\end{array}$ \\
\hline
\end{tabular}

Descriptive statistics summarizing the changes of variables in the relevant periods are summarized in Table 2.

Table 2. Descriptive Statistics

\begin{tabular}{|l|c|c|c|c|c|}
\hline Variable & $\begin{array}{c}\text { No of } \\
\text { observations }\end{array}$ & Mean & $\begin{array}{c}\text { Standard } \\
\text { deviation }\end{array}$ & $\begin{array}{c}\text { Minimum } \\
\text { Value }\end{array}$ & $\begin{array}{c}\text { Maximum } \\
\text { Value }\end{array}$ \\
\hline $\operatorname{lnGDP}$ & 722 & 10.02152 & 0.816166 & 7.128356 & 11.54306 \\
\hline $\ln \mathrm{HE}$ & 722 & 7.455461 & 0.869842 & 4.420538 & 9.231065 \\
\hline $\operatorname{lnLE}$ & 722 & 4.349742 & 0.050765 & 4.071877 & 4.422004 \\
\hline $\operatorname{lnIMR}$ & 722 & 1.744959 & 0.050765 & 0.405465 & 4.500920 \\
\hline POP & 722 & 0.703472 & 0.531820 & -0.548815 & 2.890960 \\
\hline
\end{tabular}

Source: Authors' Calculations

Mean, standard deviation, maximum and minimum values of dependent variable and explanatory variables are shown in Table 2 . The standard deviation value $(0.869)$ of the $1 \mathrm{nHE}$ variable is relatively higher. The highest maximum value is seen in lnGDP (11.543) data. The lowest minimum value was determined in POP (-0.548) data. 
POSLOVNA IZVRSNOST ZAGREB, GOD. XIV (2020) BR. 1 Artekin A. Ö., Konya S.: Health expenditure and economic growth: Is the health-led growth...

Table 3. Correlation Matrix

\begin{tabular}{|l|l|l|l|l|l|}
\hline & $\operatorname{lnGDP}$ & $\operatorname{lnHE}$ & $\operatorname{lnLE}$ & $\operatorname{lnIMR}$ & POP \\
\hline $\ln \mathrm{GDP}$ & 1 & & & & \\
\hline $\ln \mathrm{HE}$ & 0.944843 & 1 & & & \\
\hline $\ln \mathrm{E}$ & 0.871667 & 0.864238 & 1 & & \\
\hline $\ln \mathrm{IMR}$ & -0.864377 & -0.826782 & -0.937927 & 1 & \\
\hline POP & -0.104239 & -0.087154 & -0.229094 & 0.295936 & 1 \\
\hline
\end{tabular}

Source: Authors' Calculations

Correlation matrix is given in Table 3.4 out of 10 correlation coefficients are less than 0.75 . 6 correlation coefficients are greater than 0.75 both as positive value and absolute value. This shows a high relationship between variables.

\section{PANEL DATA ANALYSIS RESULTS}

For the purposes of the study, panel data analysis was performed with annual variables. The following model was used to examine whether together with health expenditures, life expectancy, infant mortality rate, population growth rate rates had an explanatory effect on economic growth:

$$
\ln G D P=a i+\beta 1 i \ln H E i t+\beta 2 i \ln L E+\beta 3 i \ln I M R+\beta 4 i P O P+\varepsilon i t
$$

Here, $\mathrm{i}$ shows the countries, $\mathrm{t}$ shows time period $\mathrm{t}$ and $1 \mathrm{n}$ shows the natural logarithms.

Levin, Lin and Chu (2002), Im, Pesaran and Shin (2003), Maddala Wu (1999) and Choi (2001), Breitung (2000) panel unit root tests were used to examine the stationery stability in the study. In Table 2 Levin, Lin and Chu (2002), Im, Pesaran and Shin (2003), Maddala Wu (1999) and Choi (2001), Breitung (2000) panel unit root tests results are shown.

Table 4. Unit Root Test Results

\begin{tabular}{|c|l|c|c|c|c|}
\hline \multirow{2}{*}{ Variables } & \multirow{2}{*}{ Test } & \multicolumn{2}{c|}{ Constant } & \multicolumn{2}{c|}{ Constant+Trend } \\
\hline \multicolumn{5}{|c|}{} & \multicolumn{3}{|c|}{ Level } \\
\hline \multirow{5}{*}{$\operatorname{lnGDP}$} & & İstatistik & p-değer & İstatistik & p-değer \\
\cline { 2 - 6 } & LLC & -5.80105 & 0.0000 & 2.52166 & 0.9942 \\
\cline { 2 - 6 } & IPS & 0.9546 & 0.8301 & 2.28503 & 0.9888 \\
\cline { 2 - 6 } & Maddala Wu & 33.0624 & 0.6969 & 22.3991 & 0.9792 \\
\cline { 2 - 6 } & Choi & 41.4150 & 0.3240 & 18.7932 & 0.9962 \\
\cline { 2 - 6 } & Breitung & --- & --- & 1.05997 & 0.8554 \\
\hline \multirow{2}{*}{$\operatorname{lnHE}$} & LLC & -8.00090 & 0.0000 & 1.633902 & 0.9494 \\
\cline { 2 - 6 } & Hadri LM & & & & \\
\hline
\end{tabular}


POSLOVNA IZVRSNOST ZAGREB, GOD. XIV (2020) BR. 1 Artekin A. Ö., Konya S.: Health expenditure and economic growth: Is the health-led growth...

\begin{tabular}{|c|c|c|c|c|c|}
\hline & IPS & -1.16622 & 0.1218 & 3.32072 & 0.9996 \\
\hline & Maddala Wu & 48.1704 & 0.1248 & 25.0494 & 0.9473 \\
\hline & Choi & 113.924 & 0.0000 & 57.8405 & 0.0205 \\
\hline & Breitung & --- & --- & 3.31588 & 0.9995 \\
\hline \multirow{5}{*}{$\operatorname{lnLE}$} & LLC & -4.36303 & 0.0000 & 5.01069 & 1.0000 \\
\hline & IPS & 1.55076 & 0.9395 & 0.86449 & 0.8063 \\
\hline & Maddala Wu & 57.5956 & 0.0216 & 51.9972 & 0.0647 \\
\hline & Choi & 78.2859 & 0.0001 & 50.5124 & 0.0842 \\
\hline & Breitung & --- & --- & 10.5342 & 1.0000 \\
\hline \multirow{5}{*}{$\operatorname{lnIMR}$} & LLC & -6.46192 & 0.0000 & 0.83920 & 0.7993 \\
\hline & IPS & -1.49865 & 0.0670 & 1.68652 & 0.9542 \\
\hline & Maddala Wu & 70.8562 & 0.0010 & 41.6337 & 0.3155 \\
\hline & Choi & 84.0650 & 0.0000 & 18.7730 & 0.9962 \\
\hline & Breitung & --- & --- & 2.57720 & 0.9950 \\
\hline \multirow{5}{*}{ POP } & LLC & -1.98748 & 0.0234 & -1.02891 & 0.1518 \\
\hline & IPS & -3.99443 & 0.0000 & -5.57625 & 0.0000 \\
\hline & Maddala Wu & 95.3190 & 0.0000 & 108.395 & 0.0000 \\
\hline & Choi & 46.4478 & 0.1634 & 34.8376 & 0.6165 \\
\hline & Breitung & --- & --- & 0.82424 & 0.7951 \\
\hline \multicolumn{6}{|c|}{ First Difference } \\
\hline \multirow{5}{*}{$\Delta \operatorname{lnGDP}$} & LLC & -16.7941 & 0.0000 & -16.1389 & 0.0000 \\
\hline & IPS & -14.7419 & 0.0000 & -13.0446 & 0.0000 \\
\hline & Maddala Wu & 265.128 & 0.0000 & 213.519 & 0.0000 \\
\hline & Choi & 258.394 & 0.0000 & 214.463 & 0.0000 \\
\hline & Breitung & --- & --- & -10.5939 & 0.0000 \\
\hline \multirow{5}{*}{$\Delta \ln H E$} & LLC & -12.7978 & 0.0000 & -12.8071 & 0.0000 \\
\hline & IPS & -14.6487 & 0.0000 & -14.6006 & 0.0000 \\
\hline & Maddala Wu & 270.338 & 0.0000 & 259.058 & 0.0000 \\
\hline & Choi & 293.358 & 0.0000 & 291.115 & 0.0000 \\
\hline & Breitung & --- & --- & -8.57763 & 0.0000 \\
\hline \multirow{5}{*}{$\Delta \operatorname{lnLE}$} & LLC & -0.74027 & 0.0000 & -5.19732 & 0.0000 \\
\hline & IPS & -23.8597 & 0.0000 & -27.0356 & 0.0000 \\
\hline & Maddala Wu & 462.134 & 0.0000 & 593.535 & 0.0000 \\
\hline & Choi & 498.376 & 0.0000 & 694.248 & 0.0000 \\
\hline & Breitung & --- & --- & -0.85468 & 0.1959 \\
\hline \multirow{5}{*}{$\Delta \ln I M R$} & LLC & -2.49291 & 0.0063 & -2.97765 & 0.0015 \\
\hline & IPS & -5.27363 & 0.0000 & -7.41210 & 0.0000 \\
\hline & Maddala Wu & 111.561 & 0.0000 & 133.725 & 0.0000 \\
\hline & Choi & 154.985 & 0.0000 & 146.169 & 0.0000 \\
\hline & Breitung & --- & --- & -1.70080 & 0.0445 \\
\hline \multirow{5}{*}{$\triangle \mathrm{POP}$} & LLC & -8.30773 & 0.0000 & -9.84358 & 0.0000 \\
\hline & IPS & -13.3260 & 0.0000 & -12.5532 & 0.0000 \\
\hline & Maddala Wu & 252.188 & 0.0000 & 227.153 & 0.0000 \\
\hline & Choi & 213.268 & 0.0000 & 459.199 & 0.0000 \\
\hline & Breitung & --- & --- & -7.34120 & 0.0000 \\
\hline
\end{tabular}

Source: Authors' Calculations 
According to the results of the unit root test, the variables were found to be the first aware stationary in all unit root tests. In other words, variables of economic growth, health expenditure, life expentancy, infant mortality rate and population are stable at I (1) level.

After determination of the stability of the variables, cointegration tests will be applied. Pedroni (1999), Kao (1999) and Johansen Fisher (1988, 1995) applied cointegration tests.

Pedroni (1999) proposed 7 different tests. The four-panel statistic is based on the in-size approach that combines the autoregressive coefficient for unit root tests on predicted residues among different members. The next three group statistics are based on the inter-dimensional approach, which averages the individual estimated coefficients for each member in the panel. The main hypothesis of Pedroni tests are:

$H o$ : There is no co-integration for all units of the panel.

$H 1$ : There is co-integration for all units of the panel.

Table 5. Pedroni Cointegration Test Results

\begin{tabular}{|l|l|l|l|l|}
\hline Method & $\begin{array}{l}\text { Test } \\
\text { statistic }\end{array}$ & Probability & Test statistic & Probability \\
\hline Constant & 1.327889 & $0.0921^{* * *}$ & -0.263647 & 0.6040 \\
\hline Panel v testi & 0.632917 & 0.7366 & 1.467651 & 0.9286 \\
\hline Panel rho testi & -1.118191 & 0.1317 & -0.975630 & 0.1646 \\
\hline Panel PP testi & -1.656995 & $0.0488^{* *}$ & -1.976143 & $0.0241 * *$ \\
\hline Panel ADF testi & 2.397086 & 0.9917 & 3.415574 & 0.9997 \\
\hline Grup rho testi & -0.109393 & 0.4564 & 0.530974 & 0.9023 \\
\hline Grup PP testi & -2.491840 & $0.0064 *$ & -1.703909 & $0.0442 * *$ \\
\hline Grup ADF testi &
\end{tabular}

Notes: $(*)(* *)(* * *)$ represents the significance of test statistic according to $1 \%, 5 \%$ and $10 \%$ significance level.

Source: Authors' Calculations

According to the cointegration test results developed by Pedroni (1999), cointegration relationship was found according to Panel v, Panel ADF and Group ADF tests in constant model. In the model established with constant and trend, the cointegration relationship was found according to Panel ADF and Group ADF tests.

After the existence of the cointegration relationship in some tests with the application of Pedroni cointegration test, Kao cointegration test was performed. 
Table 6. Kao Cointegration Test Results

\begin{tabular}{|l|l|l|}
\hline Method & Test Statistic & Probability \\
\hline ADF & -5.379977 & $0.0000^{*}$ \\
\hline Residual Variance & 0.010773 & \\
\hline HAC Variance & 0.012263 & \\
\hline
\end{tabular}

Notes: (*) represents the significance of the test statistic according to the $1 \%$ significance level.

Source: Authors' Calculations

The Kao cointegration test is based on two basic assumptions. These assumptions are expressed as follows.

$H o:$ There is no co-integration between variables.

$H 1$ : There is co-integration between variables.

The null hypothesis was rejected according to the Kao cointegration test results. That is, the existence of the cointegration relationship has been confirmed. We applied Fisher-based Johansen cointegration test (1988, 1995). Similarly, the Johansen Fisher Panel Cointegration Test, another technique that controls the existence of cointegration, was analyzed as shown in Table 7.

Table 7. Johansen Fisher Panel Cointegration Test Results

\begin{tabular}{|l|l|l|l|l|}
\hline $\begin{array}{l}\text { Hypothesised } \\
\text { No. of CE(s) }\end{array}$ & $\begin{array}{l}\text { Fisher stat } \\
\text { (from trace } \\
\text { test) }\end{array}$ & Probability & $\begin{array}{l}\text { Fisher stat } \\
\text { (max eigen test }\end{array}$ & Probability \\
\hline None & 302.4 & $0.0000^{*}$ & 176.6 & $0.0000^{*}$ \\
\hline At most 1 & 153.1 & $0.0000^{*}$ & 94.28 & $0.0000^{*}$ \\
\hline At most 2 & 87.63 & $0.0000^{*}$ & 53.82 & $0.0461^{* *}$ \\
\hline At most 3 & 62.93 & $0.0067^{*}$ & 39.33 & 0.4103 \\
\hline At most 4 & 90.50 & $0.0000^{*}$ & 90.50 & $0.0000^{*}$ \\
\hline
\end{tabular}

Notes: (*) (**) represents the significance of the test statistic according to the significance level of $1 \%$ and $5 \%$.

Source: Authors's Calculations

Maximum eigenvalue and trace critical values are used in Johansen-Fisher Panel cointegration test. According to the test results given in Table 7, there is no cointegration relationship between the variables in both maximum eigenvalue and trace test null hypothesis is rejected at $\% 1$ and $\% 5$ significance level. The alternative hypothesis supporting the existence of cointegration is accepted.

Three tests were performed to determine the presence of cointegration in the model. Pedroni, Kao, and Johansen Fisher Panel Cointegration Tests show cointegration in the model. When the variables used in the model are considered as a whole, It can be 
stated that economic growth, health expenditure, life expentancy, infant mortality rate and population variables are cointegrated. After determining the cointegration relationship between the variables, regression estimation was performed.

The Hausman Test was used to determine whether the fixed effects or random effects model is valid for 19 OECD member countries. According to the test results, the fixed effects model gave more effective results for all variables. For this reason, constant effects method is used in estimating the panel regression equation.

Table 8. Fixed Effects Panel Regression Equation Results

\begin{tabular}{|l|l|l|l|l|}
\hline Variable & Coefficient & $\begin{array}{l}\text { Standard } \\
\text { deviation }\end{array}$ & t statistic & Probabilite \\
\hline C & -2.928640 & 1.976334 & -1.481855 & 0.1389 \\
\hline $\ln H E$ & 0.561034 & 0.041692 & 13.45669 & $0.0000^{*}$ \\
\hline $\operatorname{lnLE}$ & 2.061865 & 0.463410 & 4.449329 & $0.0000^{*}$ \\
\hline lnIMR & -0.164966 & 0.044636 & -3.695825 & $0.0002^{*}$ \\
\hline R2=0.978 D-W Stat: 0.354 & F-Stat (Prob): $509.9110(0.0000)$ \\
\hline
\end{tabular}

Notes: (*) represents the significance of the test statistic according to the significance level of $1 \%$.

Source: Authors's Calculations

According to Table 8, the approximate value of the Durbin Watson $(0.354)$ statistics in the model developed according to the fixed effects model was found to be below the meaningful (2). F test statistic and probability values; the model is generally meaningful; the value of independent variables is high and approximately $98 \%$. When the t-statistics and probability values of the independent variables are examined, it is seen that each of them is meaningful at $1 \%$ significance level. It is seen that the model, which is statistically significant, is compatible with the expectations in economic terms.

\section{CONCLUSIONS}

Undoubtedly, many factors affect economic growth. However, the basis of all these factors is the investment in human beings, namely qualified manpower. On the other hand, health expenditures made to increase the health level of the individual and society have an impact on economic growth by increasing the human capital of the countries.

Health expenditures of countries vary according to their level of development. Particularly in developed countries, the share of health expenditures is higher than in developing countries. Thus, the share of health-related variables (health expenditures, life expectancy, infant mortality rate and population growth) is high for the OECD countries we have discussed in our study.

In our study, for the period of 1980-2017, we used panel data analysis to test whether the health expenditures had an explanatory effect on economic growth by using annual data. For 19 OECD countries, the results show that health expenditures have a 
relationship with GDP. Pedroni, Kao and Johansen Fisher cointegration test results show that long-term health expenditures and other explanatory variables have an impact on economic growth. In other words, the findings support the health-oriented growth hypothesis for OECD countries.

The results of the regression equation with fixed effects model showed that the effect of health expenditures on economic growth was positive. These results indicate that the impact of health expenditures on economic growth meets our expectations.

In our study, the health-led growth hypothesis was examined only for the OECD country group. Further studies with other country groups may be made for a clearer assessment. This point constitutes the limit of our study. In the next stage of our study, it is aimed to make a model estimation of countries by determining descriptive statistics for each country belonging to 19 countries.

Increasing health expenditures and improving health policies will increase the health level, efficiency and quality of the community for all countries. This increase will lead to an increase in economic growth. Countries' sustainability of economic growth will be realized with the importance given to health expenditures.

\section{REFERENCES:}

1. Badri, A.K. and Badri, S.K. (2016). Health Spending and Economic Growth in Selected OECD Countries. AIS (American Institute of Science), American Journal of Clinical Neurology and Neurosurgery, 2 (1), 5-9.

2. Baltagi, B.H. and Moscone, F. (2010). Health Care Expenditure and Incame In The OECD Reconsidered: Evidence From Panel Data. Discussion Paper, No:4851, March, IZA, P.O. Box 7240, 53072, Bonn, Germany, 1-22.

3. Beraldo, S., Montolio, D. and Turati, G. (2009). Healthy, Educated and Wealthy: A Primer on the Impact of Public and Private Welfare Expenditures on Economic Growth. The Journal of Socio-Economics, 38, 946-956.

4. Breitung, J. (2000). The local power of some unit root tests for panel data. Advances in Econometrics, Volume 15: Nonstationary Panels, Panel Cointegration, and Dynamic Panels, ed. B. H. Baltagi, Amsterdam: JAY Press, 161-178.

5. Choi, I. (2001). Unit root tests for panel data. Journal of International Money and Finance, 20, 249-72.

6. Çetin, M. and Ecevit, E. (2010). Sağlık Harcamalarının Ekonomik Büyüme Üzerine Etkisi: OECD Ülkeleri Üzerine Bir Panel Regresyon Analizi. Doğuş Üniversitesi Dergisi, 11(5), 166- 182.

7. Gyimah-Brempong, K. and Wilson, M., 2004. "Health Human Capital and Economic Growth in SubSaharan African and OECD Countries", The Quarterly Review of Economics and Finance, Vol: 44, 296-320.

8. Hansen, P. and King, A., 1996. "The Determinants of Health Care Expenditure: A Cointegration Approach," Journal of Health Economics, No:15 (1), 127-137 
9. Hartwig, J. (2010). Is Health Capital Formation Good for Long-term Economic Growth?-Panel Granger-causality Evidence for OECD Countries. Journal of Macroeconomics, 32, 314- 325.

10. Heshmati, A. (2001). On The Causality Between Gdp And Health Care Expenditure In Augmented Solow Growth Model. SSE/EFI Working Paper Series İn Economics And Finance, No:423, 1-19, January

11. Im, K. S., Pesaran, M. H. and Shin, Y. (2003). Testing for unit roots in heterogeneous panels. Journal of Econometrics, 115, 53-74.

12. Johansen, S. (1988). Statistical Analysis of Cointegration Vectors. Journal of Economic Dynamics and Control, 12(2-3), 231-254.

13. Johansen, S. (1995). Likelihood-based inference in cointegrated vector autoregressive models. Oxford University Press, USA. 280

14. Kamac1, A. And Uğurlu-Yazıc1, H. (2017) OECD Ülkelerinde Sağlık Harcamalarının Ekonomik Büyüme Üzerindeki Etkisinin Ekonometrik Analizi. Sakarya İktisat Dergisi, 6 (2). 52-69.

15. Kao, C. (1999). Spurious Regression and Residual-Based Tests for Cointegration in Panel Data. Journal of Econometrics, 90(1), 1-44.

16. K1lıç, R. And Özbek, R.İ. (2018). Sağlık ve Eğitim Hizmetleri ile Ekonomik Büyüme İlişkisi: OECD Ülkeleri Uygulaması. Ordu Üniversitesi Sosyal Bilimler Araştırmaları Dergisi, 8(2), 369-391.

17. Levin, A., Lin, C. F. and Chu, C. S. J. (2002). Unit root test in panel data: asymptotic and finite sample properties. Journal of Econometrics, 108,.1-24.

18. Maddala, G. S. and Wu, S. (1999). A comparative study of unit root tests with panel data and a new simple test. Oxford Bulletin of Economics and Statistics, special issue, 631-652.

19. Pedroni, P. (1999). Critical Values for Cointegration Tests in Heterogeneous Panels with Multiple Regressors. Oxford Bulletin of Economics and Statistics, 61, 653-670.

20. Tıraş, H.H and Ağır, H. (2018) OECD Ülkelerinde Sağlık Harcamaları ve Ekonomik Büyüme İlişkisi: Panel Nedensellik Analizleri. Siyaset, Ekonomi Ve Yönetim Araştırmaları Dergisi, 6(4). 13-29.

21. Uslu, H. (2018) Sağlık Harcamalarının Ekonomik Büyüme Üzerindeki Etkileri: Seçilmiş OECD Ülkeleri İçin Dinamik Panel Veri Analizi. Uluslararası Ekonomik Araştırmalar Dergisi,4(2). 99-116.

22. Wang, F. (2015). More Health Expenditure, Better Economic Performance? Empirical Evidence From OECD Countries. The Journal of Health Care Organization, Provision, and Financing, 1-5.

23. Yardımcıoğlu, F. (2012). OECD Ülkelerinde Sağlık ve Ekonomik Büyüme İlişkisinin Ekonometrik Bir İncelemesi. Eskişehir Osmangazi Üniversitesi Sosyal Bilimler Dergisi, 13 (2), 27-47.

24. Yerdelen F., 2011. "The Relationships between Human Capital Investment and Economic Growth: A Panel Error Correction Model". Journal of Economic and Social Research Vol 13. 


\title{
IZDACI ZA ZDRAVLJE I EKONOMSKI RAST: JE LI HIPOTEZA RASTA VOĐENA ZDRAVLJEM POTVRĐENA U IZABRANIM OECD ZEMLJAMA?
}

\author{
Ayşe Özge Artekin \& Sevilay Konya
}

\begin{abstract}
Sažetak
Cilj ove studije je istražiti hipotezu rasta vođenog zdravljem u izabranih devetnaest zemalja OECD-a. Zbog toga su u ovoj studiji primijenjeni različiti testovi kointegracije kako bi se istražila povezanost zdravstvenih rashoda i gospodarskog rasta za razdoblje 1980.-2017. Koeficijenti panel regresije procijenjeni su metodom fiksnog učinka. Prema rezultatima pronađena je dugoročna veza između zdravstvenih rashoda $i$ gospodarskog rasta. Hipoteza rasta predvođena zdravljem provedena u izabranim zemljama OECD-a (Australija, Austrija, Belgija, Kanada, Danska, Finska, Island, Irska, Japan, Koreja, Nizozemska, Norveška, Portugal, Španjolska, Švedska, Švicarska, Turska, Velika Britanija, Sjedinjene Države) je potvrđena. Drugim riječima, pronađena je dugoročna veza između izdataka za zdravstvo i gospodarskog rasta.
\end{abstract}

Ključne riječi: rast pod vodstvom zdravlja, kointegracijski test, zemlje OECD-a. 